\title{
線対平行平板電極形電気集じん装置に おける流れ場の解析と実験
}

$\begin{array}{llll}\text { 正員大久保 } & \text { 利 } & \text { (大分大) } \\ \text { 非会員村上 } & \text { 昭 年 } & \text { (九州大) } \\ \text { 正員 足 立 宜 良 (大分大) }\end{array}$

\section{1. まえがき}

電気集じん装置（以下 ESP と省略）は，コロナ放 電により発生したイオンでダスト粒子を荷電し，この 荷雪粒子をクーロン力により集じん極へ捕集するとい う，比較的簡単な原理を用いたものである。しかし， ESP 空間に拐引るダスト粒子心挙動は電流分布や電 界分布などの電気的条件およびガス流れのパターンと 相互に密接に関連しており，乙れらの条件によっては

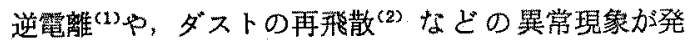
生し，急激な集しん率の低下をきたす。ESP内の流 れ場を形成する要因としては，ESP の形状，ガスの流 入速度拈よびコロナ放電によって発生したイオンが空 気の分子之衝突して起こるイオン風 ${ }^{(3)}$ な゙であるっ 口ナ放電が ESP 内の流れ場に及ほ亦影響電気流体 力学的に解明するととは ESP の集じん機能を明らか にする基碟研究として㻎要である。

足立らは電極間距離 $5 \mathrm{~cm} の$ 針対平板電極系にお いて流速と王力を用いて，Navier-Stokes の方程式を 数值解析し，レーザドップラ流速計で测定したイオン

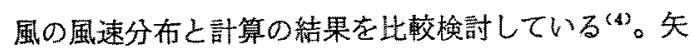
部民らは笔極間距離 $2 \mathrm{~cm}$ の線対平板電極系によいて 珮度亡流れ関数を用いて陽解法による差分法でイオン 風を解析している ${ }^{(5)}$ 。最近，山本氏らは平板電極間距 離 $6 \mathrm{~cm}$ の線対平行平板形の模擬 ESP に放いて佩度と 流れ関数を用いた陽解法による差分法で流れ埸を解析

Analytic and Experimental Study of Flow Field for Wire-Duct Type Electrostatic Precipitator. By Toshikazu Ohkubo, Member (Faculty of Engineering, Oita University), Terutoshi Murakami, Non-member (Faculty of Engineering, Kyusyu University) \& Takayoshi Adachi, Member (Faculty of Engineering, Oita University).

大久保利一; 正是, 大分大学工学部露気工学科

村上昭年：非会夏，九州大学工学部応用理学教室

足立宜良: 正員，大分大学工学部要気工学科
し，上流の熱線からの加熱気流のシュリーレン写真拈 よびミスト粒子を用いたトレーサ法による写真撮影の 結果亡比較考察を行った ${ }^{(6)}$ 。しかし，実用 ESP サイ ズの線刘平行平板形 ESP (平板電極間隔が 20-25 cm) については解析招よじ実験の報告例はなく、コロナ放 電が军用 ESP 内の流れ場に及ぼす影響については解 明されていない。

本報告では，平板間隔 $20 \mathrm{~cm}$ の線対平行平板電極形 ESP のダスト粒子が沶い場合の流れ場を電気流体力 学的に解析した。流れ場の解析では，非任維性流体の Navier-Stokes の式と連綂の式洞度と流れ関数の式 の連立腐微分方程式飞变形して ${ }^{(5)(6)}$, ADI 法 (AIternating Direction Implicit method) ${ }^{(7)}$ をいて計算 した。Navier-Stokes の方程式中の外力としてのク一 ロン力は，以前啹告した平板上での露流密度分布など が非常によく実験值之一致する，Deutsch の仮定に基 つくくコロナ放電場の電界計算法 ${ }^{(8)}$ を用いて求めた。解 析では流体に及ぽす力はク一ロン力のみを考慮し，流 れ場によっでコロナ放電場は影響を受りず，放電線は 流れ場飞影掣を与えないと仮定した。

また，平板電霆近傍および ESP 内の流れ場をシュ リーレン装置在用いて可視化す矿法により実験的に 求め，計算結果との比較と検討を行った。更に、トレ ーサ法により ESP 内のタバコ煙粒子の流跡を観察し， コロナ放電および流れ場が微細粒子(サブミクロン粒 子）の挙動に及将す影璄を調べたので報告する。

\section{2. 流れ場の計算方法}

非生縮性粘性流体に対する流れ場を Navier-Stokes の式と連続の式を用いて解析する。その一般的な形は

$$
\frac{\partial \boldsymbol{q}}{\partial t}+(\boldsymbol{q} \cdot \boldsymbol{\nabla}) \boldsymbol{q}=\frac{1}{\rho} \boldsymbol{K}-\frac{1}{\rho} \boldsymbol{\nabla} p+\nu \boldsymbol{\nabla}^{2} \boldsymbol{q}
$$

昭 $61-8$ 


$$
\nabla \cdot \boldsymbol{q}=0
$$

である。とこで, $\boldsymbol{q}$ は速度へクトル, $t$ は時間, $\rho$ は 空気の密度, $\boldsymbol{K}$ は外力, $p$ は王力, 山は動粘性率であ る。コロナ放電に伴い発生したイオンは集じん極へ移 動する際に中性分子と衝突してエネルギーを与え中性 分子を移動させる。本研究では，イオンに劺くクーロ ン力と中性分子に僄く力が平衡していると仮定して, 外力項はクーロン力密度

$$
\boldsymbol{K}=\rho_{i} \boldsymbol{E}
$$

のみを考慮した。ととで， $\boldsymbol{E}$ は電界強度， $\rho_{i}$ はイオ ンの空間電荷密度である。線対平行平板形電気集じん 装置内の流れ場は二次元的な定常流であるとした。し かし，その場合の境界条件がわかっていないので，計 算においては，一棣流速 $U_{0}$ の初期条件の下に，次の (4) (6)式として定義される流れ関数 $\Psi$, 渦度 $\omega$ を変数とした Navier-Stokes の式を時間項で繰り返 し, 流れ関数之渦度の時間的変化が小さくなるまで時 間を進めて解とした。

$$
\begin{aligned}
& u=\frac{\partial \Psi}{\partial y} \\
& v=-\frac{\partial \Psi}{\partial x} \\
& \omega=-\left(\frac{\partial^{2} \Psi}{\partial x^{2}}+\frac{\partial^{2} \Psi}{\partial y^{2}}\right)
\end{aligned}
$$

ここで, $u$ は $x$ 方向, $v$ は $y$ 方向の速度である。 連続の式(2)は, 速度の成分を(4),(5)式の上うに 定義すると自動的に満たされる。流れ関数上渦度を用 いて(1)式を変形すると次式が得られる(6)(7)。

$$
\begin{aligned}
\frac{\partial \omega}{\partial t}= & -\frac{\partial \Psi}{\partial y} \frac{\partial \omega}{\partial x}+\frac{\partial \Psi}{\partial x} \frac{\partial \omega}{\partial y}+\nu\left(\frac{\partial^{2} \omega}{\partial x^{2}}+\frac{\partial^{2} \omega}{\partial y^{2}}\right) \\
& +\frac{1}{\rho}\left(-\frac{\partial \rho_{i}}{\partial x} E_{y}+\frac{\partial \rho_{i}}{\partial y} E_{x}\right) \ldots \ldots \ldots
\end{aligned}
$$

次式のように無次元化を行い，変数の右肩に*を付け て無次元化した量を示す。

$$
\left.\begin{array}{l}
x^{*}=x / D, y^{*}=y / D, t^{*}=U_{\mathrm{EHD}} t / D \\
\rho_{i}^{*}=\rho_{i} / \rho_{i 0}, E^{*}=D E / V \\
\omega^{*}=D \omega / U_{\mathrm{EHD}}, \quad \Psi^{*}=\Psi /\left(U_{\mathrm{EHD}} D\right) \\
\rho_{i 0}=J_{p} D /(\mu V), U_{\mathrm{EHD}}=V \bar{J}_{p} D /(\mu \rho)
\end{array}\right\}
$$

こてで, $2 D$ は平板間隔, $V$ は肺加電圧, $J_{p}$ は放電 線直下の平板電極上の電流密度である。U $U_{\mathrm{EHD}}$ は中性 分子の $\mathrm{EHD}$ 特性速度である。無次元化した变数を用 いて $(7),(6)$ 式は

$$
\begin{aligned}
\frac{\partial \omega^{*}}{\partial t^{*}}= & -\frac{\partial \Psi^{*}}{\partial y^{*}} \frac{\partial \omega^{*}}{\partial x^{*}}+\frac{\partial \Psi^{*}}{\partial x^{*}} \frac{\partial \omega^{*}}{\partial y^{*}} \\
& +\frac{1}{R_{\mathrm{EHD}}}\left(\frac{\partial^{2} \dot{\omega}^{*}}{\partial x^{* 2}}+\frac{\partial^{2} \omega^{*}}{\partial y^{* 2}}\right)
\end{aligned}
$$

$$
\begin{gathered}
-\frac{\partial \rho_{i}^{*}}{\partial x^{*}} E_{y} *+\frac{\partial \rho_{i}^{*}}{\partial y^{*}} E_{x} * \\
\frac{\partial^{2} \Psi^{*}}{\partial x^{* 2}}+\frac{\partial^{2} \Psi^{*}}{\partial y^{* 2}}=-\omega^{*} \ldots \ldots \ldots \ldots
\end{gathered}
$$

となる。ここで, REHD は電気流体力学レイノルズ数 と呼ばれ,

$R_{\mathrm{EHD}}=D U_{\mathrm{EHD}} / \nu$

である。

(9)式は，流れ関数 $\Psi$ を既知として，渦度 $\omega$ につ いて計算する。陽解法では時間刻み $\Delta t$ と空間刻み $\Delta x, \Delta y$ の間に安定条件が存在し(5), 時間刻みが大き くできないたや，数值計算化多くの時間を消費する。 本論文では，陽解法と比へててが大きくても安定で手 間が少ないといわれている ADI 法(8)を用いた。

(10)式はポアソンの方程式の形をしており，ADI法 で求めた $\omega$ を用いて有限要素法によりせを計算した。 (9)，(10)式を交互偣計算して流れ場が定常になるま で時間を進めた。収束の判定は, 渦度と流れ関数につ いて各点の時間変化割合の絶対値を総和してその大き い方を誤差 $\varepsilon$ として， $\varepsilon$ を収束判定值と比較するてと により行った。(9)式で, 外力の項は, Deutsch の仮 定に基つく電界計算法により計算し，電荷密度分布お よび電界分布はイオンの移動速度が ESP 内の代表的 なガス流速 $0.8 \sim 1 \mathrm{~m} / \mathrm{s}$ に比へて非常に速いので流れ 場の影響を受けないとした。

流れ場の計算領域と境界条件について図 1 亿示す。 放電線は，平行平板の中心に位置しており，放電線を 境に上下に効称なので，計算領域は半分とし， $D=10$ $\mathrm{cm}$ ，集じん極の長さ $L$ を 5 と $8 D$ の場合について 解析を行った。 $x$ 方向, $y$ 方向と屯等間隔に分割し, その格子点数は $L=5 D$ の場合 $51 \times 11, L=8 D$ の場 合 $161 \times 21$ とした。有限要素法の要素は差分法の格子 点加ら三角形要素を作成し，要素内で渦度は 1 次関数 で近似した。直径 $d=0.5 \mathrm{~mm}$ の放電線は流机場倍 響を与えないとした。ESP 入口の境界条件は，ガス 流入速度 $U_{0}$ となるように $\Psi$ を固定し，ガス出口で

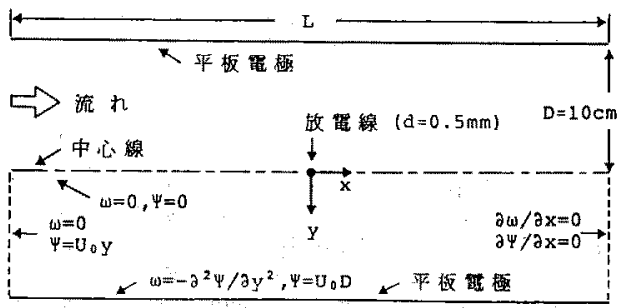

因 1 計算領域之境界条件

Fig. 1. Calculation region of ESP and boundary conditions. 
は自然境界条件を適芯した。また，領域全体に $u=U_{0}$, $v=0$ となる $\Psi$ と $\omega=0$ 初期条件として与えた。

\section{3. 実験装置と測定方法}

実験装置の概略図を図 2 亿示す。実験装固は一様な 気流を発生するための送風部之線対平行平板形 ESP 部とからなる。シロッコファン形送風機からの空気流

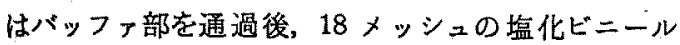
製網および直径 $6 \mathrm{~mm}$ のストローから構成された整 流部で整流し，ESP 内に導入される。観測部の側面に はアクリル板を取付けてあり，ESP 内部の流れ場を 観察できる。基礎的な ESP の特性を調べるため，直 径 $d=0.5 \mathrm{~mm}$ のステンレス製の放電線 1 本だけを観 測部の中央に配置した。

集しん極は縁端効果対策を施した鉄製の平板電極 $(100 \times 60 \mathrm{~cm})$ からなり, 平板間隔 $2 D$ は実用 ESP 使 用される $20 \mathrm{~cm}$ に設定した。真極性のコロナ放電の 場合，放電線にそってイオン風の吹き出し点が点在す るため ${ }^{(9)}$ ，ESP 内の流机は放電線の近傍で 3 次元的 に乱れていると考えられる。そこで，本論文では ESP 内の流れ場の基礎的な特性を調べるため，実験はイオ ン風が安定で一様である正極性のコロナ放電を用いて 行った。コロナ電流密度分布の测定は下側平板電極に 埋設した 41 本の長方形プローブ $(4 \times 200 \mathrm{~mm})$ に流れ るコロナ電流を微少電流計 (YHP 4304 B) で測定し， 実效プローブ面皘で割って算出した。但し，プロープ と平板電極との間げきを $0.5 \mathrm{~mm}$ とし, この間にエポ キシ系樹脂をつぬて十分な絶縁を施し，プローブのな い平板電極の放電特性と同じになるよう配慮した。

コロナ放電の ESP の流机場への影響を調べるたる 図 3 亿示すように放電線の上流側 $30 \mathrm{~cm}$ の位置に放 電線之平行に長さ $20 \mathrm{~cm}$ 直径 $0.15 \mathrm{~mm}$ のニクロム線 を $2 \mathrm{~cm}$ 間隔で 5 本張り，一本あたり $0.7 \mathrm{~A}$ の電流に より約 $50^{\circ} \mathrm{C}$ (静止大気中) に加熱した。この熱線によ る加熱気流の流跡を 2 面対向法によるシュリーレン装 置により観察した。また，平板電極近傍のうずを観測 する場合は，熱線からの加熱気流はうずの中に入らな いので，下側平板電極に直径 $5 \mathrm{~mm}$ の加熱プローブ を埋設し，平板電極近傍の気流を加熱して流れ場の可 視化を行?た。シュリーレン装置は直径 $300 \mathrm{~mm}$ の 2 枚の凹面鏡および $500 \mathrm{~mm}$ の望遠レンズのカメラから 構成されている。

また，微細粒子の ESP 内での挙動を調べるため， 図 4 に示すように上流側に配置した内徍 $1.7 \mathrm{~mm}$ のノ ズルからタバコ煙粒子を気流と平行に導入し，その流 跡の写真撮影を行った。ダスト粒子として柆径が小さ

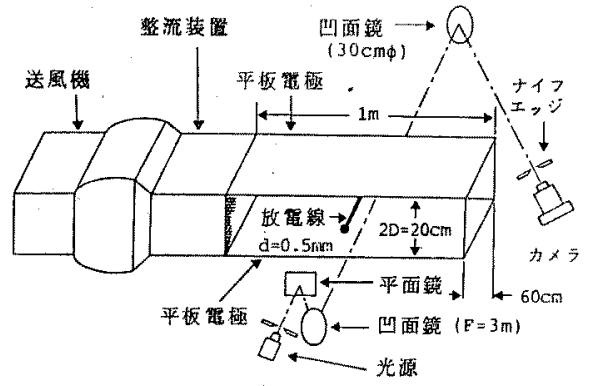

図 2 実験萃置の概略図

Fig. 2. Schematic diagram of experimental apparatus.

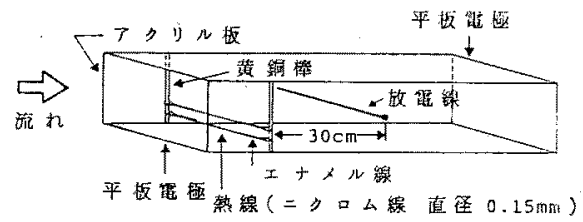

因 3 ESP内の流れ場の可視化に用いた加熱装置

Fig. 3. Heating apparatus for visualization of flow field in ESP.

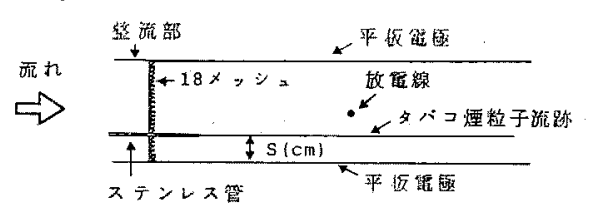

図 4 タバコ煙粒子の導入㳖置

Fig. 4. Experimental apparatus to introduce particles of tobacco smoke.

く（サブミクロン粒子）荷電量が少ないため気流に比 ベて電界の影響を受けにくく，ほぼ気流に沿って流れ ると考えられている(11)，タバコ煙粒子を用いた。なお 実験は大気中（室温約 $27^{\circ} \mathrm{C}$, 湿度約 $75 \%$ ）で行い， ESP 内の気流は実用 ESP で一般に使われている 0.8 $\mathrm{m} / \mathrm{s}$ とした。

\section{4. 結果と検討}

〈4・1〉 電界分布 Navier-Stokes の式の外力項 としてのクーロン力密度は以前報告した Deutsch の 仮定による計算手法を用いて計算した ${ }^{(8)}$ 。図 5 は正極 性コロナ放電に扣りる電圧電流特性の実験值と計算值 の比較を示す。計算に吉いてはピークの式のコロナ開 始電界強度を用い正イオンの移動度を $1.4 \mathrm{~cm}^{2} / \mathrm{V} \cdot \mathrm{s}$ 之 した。また，平板電極上での電流密度分布および電界 強度分布の計算值は実験㯖之非常によく一致する。従 って，ESP 空間内の電界分布むとの手法により計算 可能であると考えられる。 


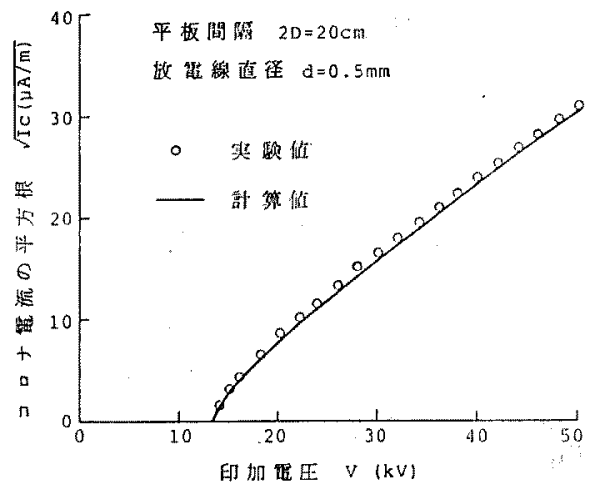

図 5 正極性コロナの放電特性

Fig. 5. Corona discharge characteristic for positive corona.

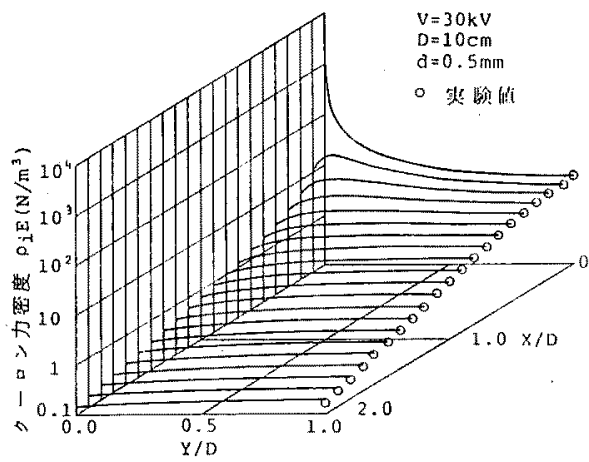

园 6 ESP 内のクーロン力密度分布

Fig. 6. Distribution of Coulomb force density in ESP space.

ESP 内のクーロン力密度分布の親值を図6亿示 す。困中に示す平板電極上のクーロン力密度の実験值 は平板電極上の電流密度 $J$ の測定值䘮用いて, $\rho_{i} E=$ $J / \mu$ より算出した。クーロン力密度は放電線から離れ るに従って急激に減少し，2.5D 以上でははとんど零 となる。この結果から流れ場の解析では放電線から $2.5 \mathrm{D}$ 以上の上ころではクーロン力密度を無視した。

\section{$\langle 4 \cdot 2\rangle$ 流れ場の解析結果 . 数值計算において，} $\Delta t=r \Delta h^{2}$ となる時間刻みを用い, $r=1.0$, 収束条件 $\varepsilon=10^{-4}$ とした。ここで, $\Delta h=\Delta x=\Delta y$ である $r=$ 0.5 と 1.0 の場合を比較すると $r$ による流れ関数の 相対誤差は各点において $10^{-3}$ 以下であった。

入口ガス流速 $U_{0}=0.8 \mathrm{~m} / \mathrm{s}$ 一定の場合の流れ関数 の計算結果を，印加電生をパラメータにして図 7 に示 す。この四は領域の長さ $L=8 D(161 \times 21)$ で解析 した結果を放電線を中心として $5 D$ の領域の部分を园 示している。 $L=5 D(51 \times 11)$ のさい領域で大きい 格子間隔におりる計算結果と $L=8 \mathrm{D}(161 \times 21)$ の場合

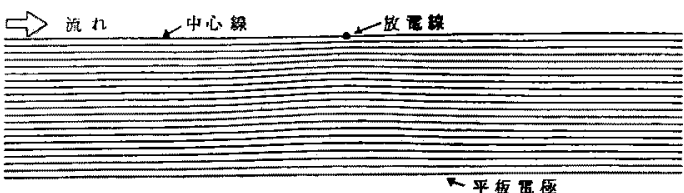

(a) $V=30 \mathrm{kV}, \mathrm{N}_{\mathrm{QHD}}=0.86, I_{c}=0.24 \mathrm{~mA} / \mathrm{m}$

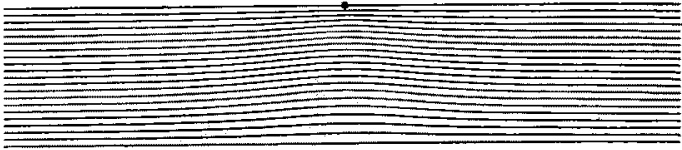

(b) $\mathrm{V}=40 \mathrm{kV}, \mathrm{N}_{\mathrm{EHO}}=1.27, I_{c}=0.53 \mathrm{~mA} / \mathrm{m}$

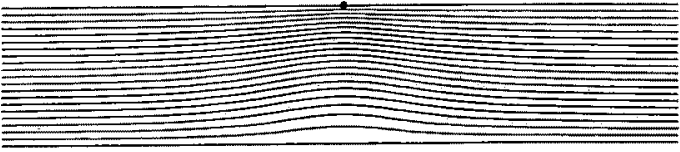

(c) $V=50 \mathrm{kV}, \mathrm{N}$ EHD $=1.67, I \dot{c}=0.92 \mathrm{~mA} / \mathrm{m}$

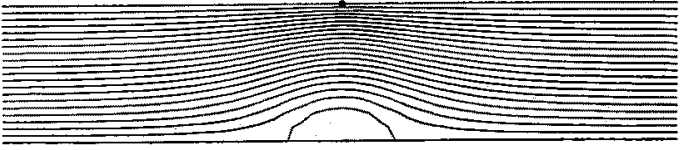

(d) $V=60 \mathrm{kV}, \mathrm{N}_{\mathrm{g} \neq \mathrm{D}}=2.07, \mathrm{IC}_{\mathrm{C}}=1.41 \mathrm{~mA} / \mathrm{m}$

园 $7 U_{0}=0.8 \mathrm{~m} / \mathrm{s}$ の場合の流れ関数の計算值 (印加電压をパラメータ)

Fig. 7. Calculated stream line for $U_{0}=0.8 \mathrm{~m} / \mathrm{s}$ with applied voltage as a parameter.

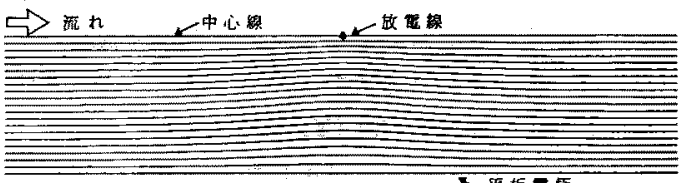

(a) $0_{0}=0.6 \mathrm{~m} / \mathrm{s}, N_{\text {end }}=1.14$

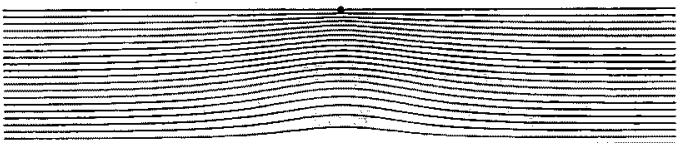

(b) $u_{0}=0.4 \mathrm{~m} / \mathrm{s}, \mathrm{v}_{\mathrm{EHD}}=1.71$

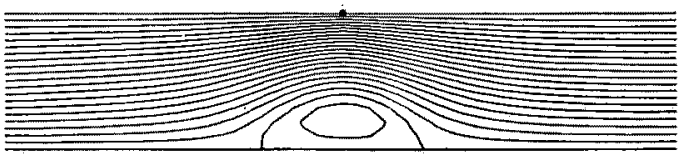

(c) $U_{0}=0.3 \mathrm{~m} / \mathrm{s}, \mathrm{N}_{\mathrm{EHD}}=2.29$

図 $8 V=30 \mathrm{kV}$ の場合の流れ関数の計算值

(入口流速をパラメータ)

Fig. 8. Calculated stream line for $V=30 \mathrm{kV}$ with inlet flow velocity as a parameter.

を比較すると各点の流れ関数の相対誤差は $2 \times 10^{-3}$ 以 下であった。また，用加電圧 $30 \mathrm{kV}$ 一定で，ガス流 速を $0.3 \sim 0.6 \mathrm{~m} / \mathrm{s}$ とした場合の流れ関数を図 8 に示 すे。

図7，目8中の $N_{\mathrm{EHD}}$ は代表的なイオン風速 $U_{\mathrm{EHD}}$ とガス流入速度 $U_{0}$ の比であり， $N_{\mathrm{EHD}}=U_{\mathrm{EHD}} / U_{0}$ で 定義される EHD 数である。 $N_{E H D}$ はイオン風の相対 
的な強さを表わし，無次元化した式における流れ場の 相似性を示す数である。図 7 と図 8 から $N_{\text {EHD におけ }}$ る流れ場の相似性がほぼ成り立つととがわかる。一 方, 放電線上の電荷密度 $\rho_{i} w$ と印加電圧 $V$ を用いて

$$
U_{\mathrm{EHD}}=\sqrt{\rho_{i \mathrm{~W}} V / \rho}
$$

で定義した代表的なイオン風速を用いて， $N_{E H D}=$ $U_{\mathrm{EHD}} / U_{0}$ を評価する方法がある(6)。しかし, 本論文

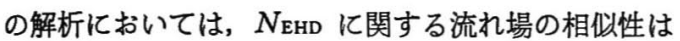
山本氏らの諭文 ${ }^{(6)}$ に定義された $N$ EHD に関してではな

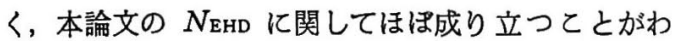
かった。これは, 放電線上の電界強度 $E_{W}$ がコロナ開 始電圧以上ではコロナ開始時の電界強度にほほ一定と 考えられるため, 放電線上のク一ロン力密度 $\rho_{i} w E_{W}$ は $\rho_{i} w V$ ではなくて $\rho_{i} w$ に依存しているからである。

流線は上流側で, 放電線方向に引きよせられ, 下流 側で平板方向に戻される。 $N_{\mathrm{EHD}}$ が約 2 以上になると イオン風の効果が大きくなり, 放電線直下の平板電極 近傍にうずが発生する。 $\varepsilon=10^{-4}$ の場合, $N_{E H D}$ がお よそ 2.5 以下では収束が得られたが， 2.5 以上では収 束を判定するための誤差值は振動を続け, 計算值は収 束しなかった。この理由は, 境界層の影響を正確に取 入れてないためエネルギー散逸の効果が小さく，うず を抑制する力が働かないためと考えられる。

$V=40 \mathrm{kV}, U_{0}=0.8 \mathrm{~m} / \mathrm{s}$ の場合の流速ベクトルと 最大值で規格化した渦度の分布の一例を図 9 に示す。 ESP 内の速度分布は, うずが発生していない場合, 放電線近傍で速度が大きく，うずが発生している場 合，うずのまわりで速度が大きくなる。図9(a)の場 合, 流速は放電線の近傍で最大 $1.2 \mathrm{~m} / \mathrm{s}\left(1.5 U_{0}\right)$ で,

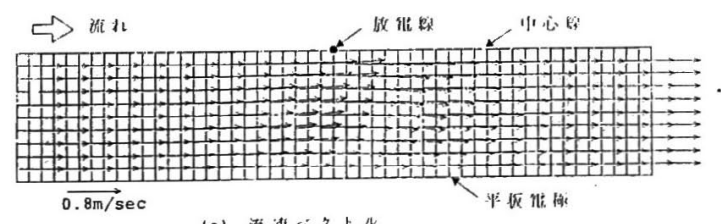

(a) 流涑二马トn

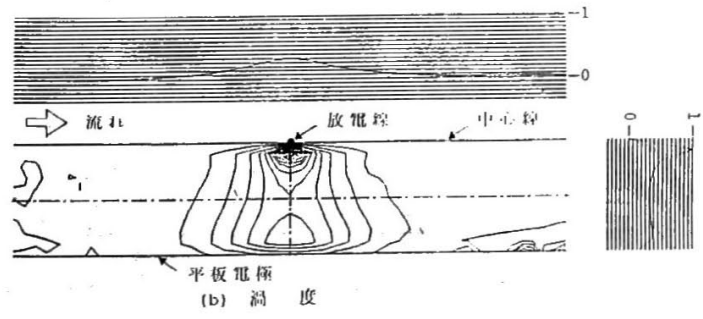

図 $9 V=40 \mathrm{kV}, U_{0}=0.8 \mathrm{~m} / \mathrm{s}$ の場合の流速 ベクトルと渦度の分布

Fig. 9. Calculated flow velocity and distribution of vorticity for $V=40 \mathrm{kV}$ and $U_{0}=0.8 \mathrm{~m} / \mathrm{s}$.
放電線直下の平板電極近傍で最小 $0.48 \mathrm{~m} / \mathrm{s}\left(0.6 U_{0}\right)$ であった。渦度の断面図は, 一点銷線で示す断面の渦 度の値を示す。渦度は放電線の近傍で最大值を持ち, また, 平板電極近くで小さいピークを示している。

以上の流線の計算結果より, サブミクロン粒子や荷 電量の少ないダスト粒子は, 一度, 放電線方向に引き つけられ，それから，集じん電極側へ向かうものと考 えられる。N $N_{\mathrm{EHD}}$ が大きくなるとイオン風の影響が強 く現われ，うずが発生する。イオン風は，ダスト粒子 を放電線の下流側で集じん電極に押しやるように働く が，うずは集じん電極上に堆積したダスト層を吹き上 げ，ダスト粒子の再飛散現象の原因となると考えられ る。

〈4·3〉実験結果と検討 正極性コロナ放電の場 合におりる上流の熱線からの加熱気流のスパーク光源 装置を用いたシュリーレン写真を図 10 に示す。正極 性コロナ放電における流れ場は定常で，ほほ層流であ

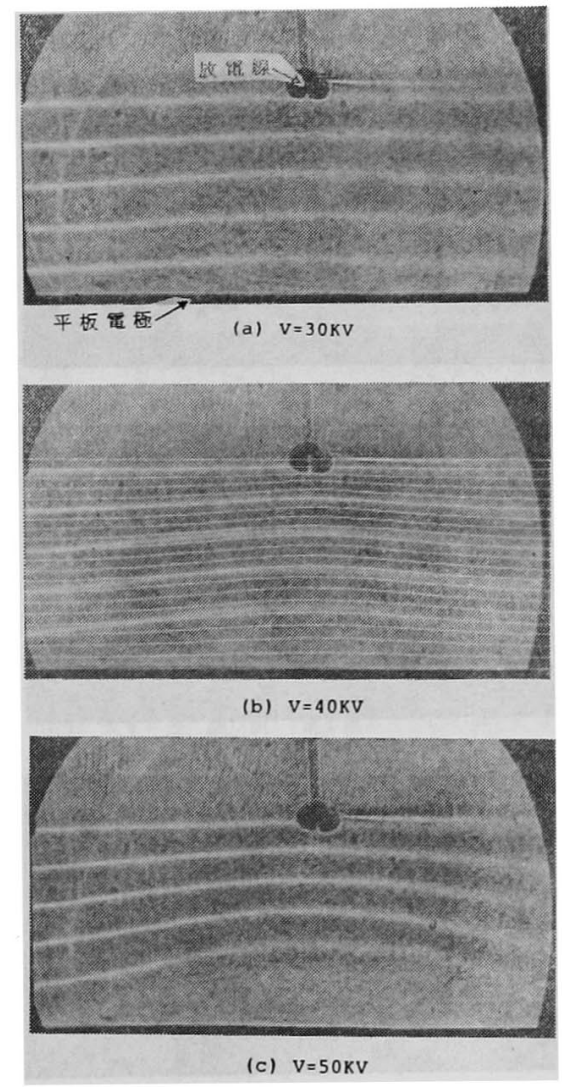

図 10 上流の熱線からの加熱気流のシュリー レン写真 $\left(U_{0}=0.8 \mathrm{~m} / \mathrm{s}\right)$

Fig. 10. Schlieren photographs of heated air from heating wires at upstream for $U_{0}=0.8 \mathrm{~m} / \mathrm{s}$. 
ったので，光源として水銀灯を用いた場合でも，同様 な結果が得られた。また， $U_{0}$ が $0.2 \mathrm{~m} / \mathrm{s}$ 以下になる と，加熱気流の影響があったが実験における $U_{0}=0.8$ $\mathrm{m} / \mathrm{s}$ の場合ほとえどなかった。従って，乙の加熱気流 の流跡は流れ場の流線を表わすと考えられる。印加電 圧 $V=20 \mathrm{kV}$ の場合, 加熱気流は平板電極とほぼ平行 に流れているが印加電圧が大きくなると，放電線の上 流側で放電線方向に引き寄せられ，下流側で平板電極 方向へ押し㞍されている。 $V=40 \mathrm{kV}$ の場合の (b) 図 はシュリーレン写真と同一条件の場合の流れ関数の計

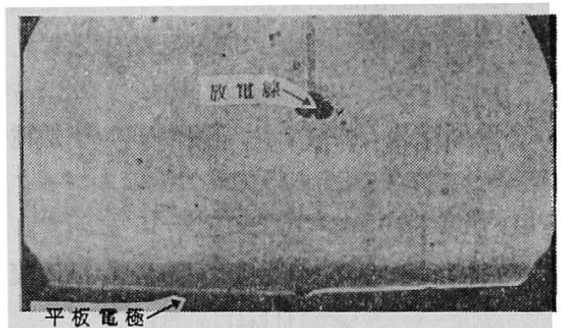

(a) $\mathrm{V}=\mathrm{OKV}$

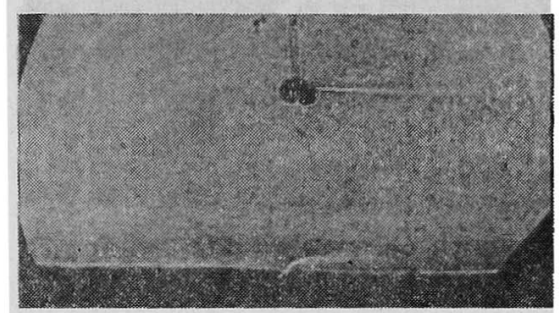

(b) $\mathrm{V}=30 \mathrm{KV}$

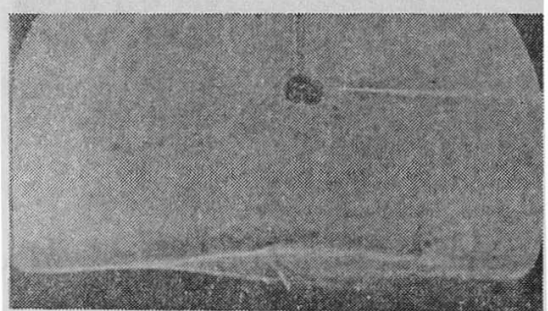

(c) $\mathrm{V}=40 \mathrm{KV}$

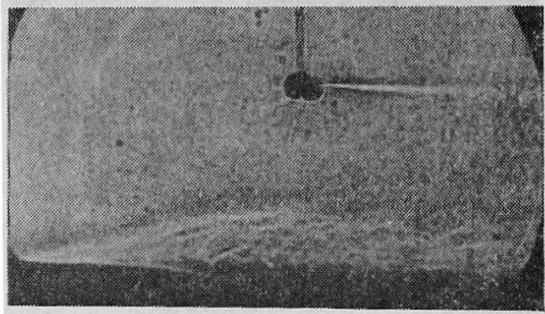

(d) $\mathrm{V}=50 \mathrm{KV}$

図 11 平板電極近傍の流れ場のシュリーレン 写真 $\left(U_{0}=0.8 \mathrm{~m} / \mathrm{s}\right)$

Fig. 11. Schlieren photographs of flow field near plate electrode for $U_{0}=0.8 \mathrm{~m} / \mathrm{s}$.
算結果を合成してある。

計算結果は多くの仮定の下に解析しているにあかか わらず，平板電極の近傍を除いて実験結果とよく一致 するととがわかった。本論文の方法では，乙れまで報 告されている方法 ${ }^{(5)(6)}$ 之異なり, 電界解析個々の装 置の実験值を必要としないため, 実験值を用いずに流 れ場の解析が可能である。

上流加らの熱線の実験では解析結果に示した平板電 極近傍のうずを可視化できない。そこで，平板電極に 埋設した加熱プローブ $(60 \mathrm{~W})$ で気流を加熱すること により平板電極近傍の流れ場をシュリーレン装置を用 いて可視化した。平板電極近傍の加熱気流は周囲温度

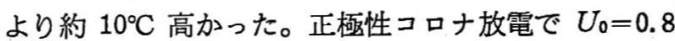
$\mathrm{m} / \mathrm{s}$ の場合の平板電極近傍の流れ場を図 11 に示す。 $V=0 \mathrm{kV}$ の場合は加熱気流はほぼ平板電極にそって 流れる。 $V=30 \mathrm{kV}$ では加熱プローブからの加熱気流 は少し立ち上り下流側に流されているが， $V=40 \mathrm{kV}$ では平板電極近傍の流速がイオン風の影響で小さくな

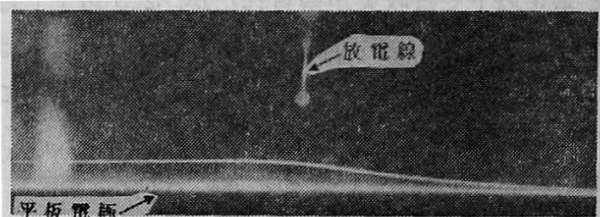

(a) $\mathrm{V}=30 \mathrm{KV}, \mathrm{S}=2 \mathrm{~cm}$

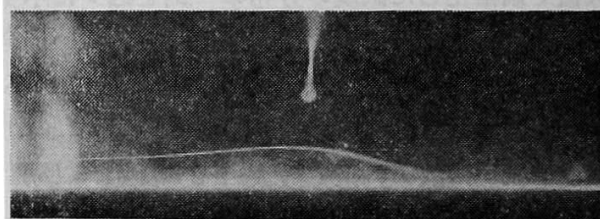

(b) $\mathrm{V}=40 \mathrm{KV}, \mathrm{S}=2 \mathrm{~cm}$

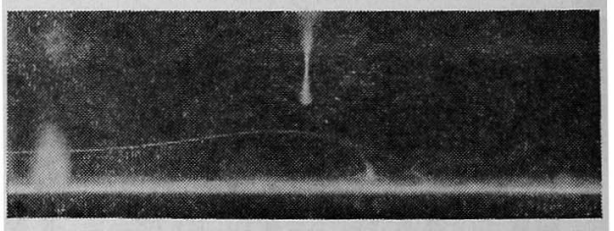

(c) $\mathrm{V}=50 \mathrm{KV}, \mathrm{S}=3 \mathrm{~cm}$

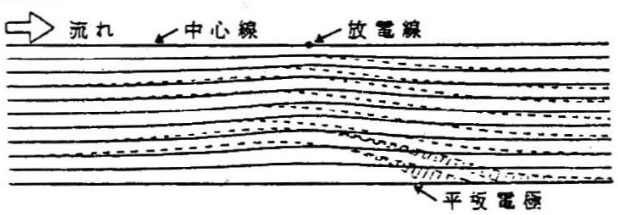

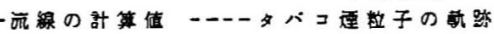

(d) $\mathrm{V}=40 \mathrm{KV}, \mathrm{U}_{0}=0.8 \mathrm{~m} / \mathrm{sec}$

困 12 タバコ煙による ESP 内の微細粒子の軌跡

Fig. 12. Trajectory of submicron particle in ESP with smoke of tobacco. 
るため，気流は垂直またはすとし上流側に流されてお り，その近傍でゆっくり摇らいでいるのが観測され た。 $V=50 \mathrm{kV}$ では放電線值下発達したうずが認め られる。とれらの結果は，20Wで加熱した場合も同 様の結果が観測されており加熱の影響は流れ場に大き く影響を与えないと考えられる。

$U_{0}=0.8 \mathrm{~m} / \mathrm{s}$ の場合のタバコ煙粒子の轨跡を図 12 に示す。印加笪王が大きくなるほど強く放電線に引き 寄せられている。熱線による加熱気流の結果に比へ て，放電線の下流側では平板電極方向により強く引き 寄せられているのは多くの微紐粒子の集合に働くク一 ロン力によるもの上考元られる。特に， $V=40 \mathrm{kV}$ 以 上では平板電極に集じんされる様子が見られる。この 四の(d)は写真加ら求めた粒子の軌跡と流れ関数の計 算傎を示す。正極性コロナ放電は故電線汇沿って均一 であるため，ESP 内の微細柆子の挙動は電気流体力学 的流れ場に密接に関連し，貧極性コロナの場合のよう にコロナ放電により乱流拡散されない。Deutsch の集 じん率の式は一様に粒子が乱流㹡散しているとの仮定 の下に導出されている(10)。従って，本実験の結果は徽 細粒子の集じん率を検討するさいの重要な基礎データ であると考えられる。

\section{5. まとめ}

線対平行平板電極形電気集じん䒾置内の流れ場をク 一ロン力密度を外力項とする Navier-Stokes の方程 式に基づき渦度と流れ関数を用いて ADI 法により数 值解析した。また，シュリーレン法を用いた実験によ り流れ場の可視化を行った。その結果をまとめると以 下のようになる。

（1）流机場の解析の結果，流線は一度放電線方向 に引き奇せられ，また平板電極方向に押し民される。 また，ESP 内の速度分布は，うずが発生していない場 合，放電線近傍で速度が大きく，うずが発生している 塨合，うずのまわりで㻋度が大きい。ガス流入速度に 対してイオン風の效果が大きくなる（NEHD が約 2 以 上）と，放電線直下の平板電極近㥬でうずが発生し た。

（2）上流の熱線からの加熱気流および平板電極に 埋設した加熱プローブを用いて ESP 内の流線术よび
平板電極近傍のうずがシュリーレン法により明りょう に可視化された。その結果, ESP 内の流れ場および 平板電極近傍のうずの生成に及济すコロナ放電の影辢 が実験的に明らかにされた。

（3）ESP 内に導入したタバコ煙柆子の轨跡は解 析の結果之同様，放電線方向に引き寄せられる。但 し、放電線より下流側ではクーロン力の影響を受りて 気流の流線上は少し異なる举動をする。

（4）本諭文の解析法は ADI 法による陰解法で㢦 算を行っており，陽解法に比べて計算の手間および計 算時間を短縮でき，個々の装置の実験值を用いずに流 れ場を解析できる点で有㚳である。との解析結果は実 験結果とよい一致を示し，ESP 内の流れ場を本諭文 の解析方法で解析できることが実証されだ。

本報告をまとめるにあたり，御討諭頂いだ赤崎正則 教授（九大総合理工），原雅則教授 (九大工学部)，野 本幸治教授（大分大工学部）施よび Jen-Shih Chang 教授 (McMaster University，カナダ) に哚く感謝す る。また，何加之御協力頂いた本学赤峰修一技官，院 生矢野博史君に感謝する。最後に，文部省昭和 61 年 度科学研究唄補助金の援助飞深く感謝する。

(昭和 60 年 11 月 29 日受付)

$$
\text { 文献 }
$$

(1) S. Masuda \& A. Mizuno: "Flashover Measurement of Back Discharge", J. Electrostatics, 4, 215 (1978)

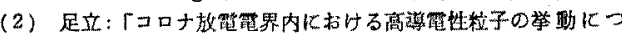
()て」, 電学誌, 90,710 (昭 45-4)

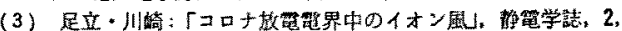
3，158（昭 53）

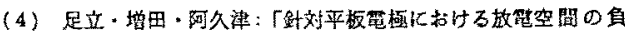

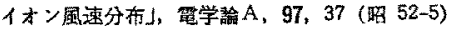

(5) A. Yahe, Y. Mori \& K. Hijikata: "EHD Study of the Corona Wind between Wire and Plate Electrodes", AIAA Journat, 16, 4, 340 (1978)

(6) T. Yamamoto \& H.R. Velkoft : "Electrohydrodynamics in an electrostatic precipitator", J. Fluid Mech., 108, 1 (1981)

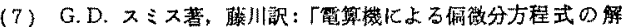
法了, p. $42($ 昭 56) サイエンス社

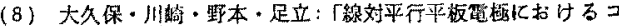

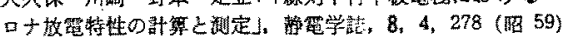

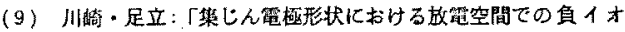

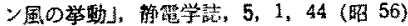

(10) H.J. White: "Yndustrial Electrostatic Precipitation", p. 165, Addison-Wesley. Massachusetts (1965)

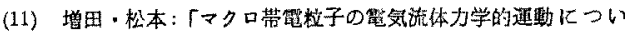

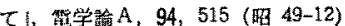

